\title{
Allyl isothiocyanate as a fumigant in the cowpea and its effect on the physical properties of the grain ${ }^{1}$
}

\author{
Isotiocianato de alilo como fumigante no feijão-caupi e seu efeito nas propriedades \\ físicas dos grãos
}

\author{
Ailyn de Oliveira Vilela², Lêda Rita D'Antonino Faroni²*, Jéssica Lino Gomes² ${ }^{2}$ Adalberto Hipólito de Sousa ${ }^{3}$, \\ Paulo Roberto Cecon $^{4}$
}

\begin{abstract}
The cowpea is subject to both quantitative and qualitative loss during storage due to attack by the insect pest Callosobruchus maculatus (Fabricius) (Coleoptera: Chrysomelidae). There is a growing interest in controlling the pest using insecticides that result from the reactions of secondary metabolites produced by plants, due to their high efficiency, wide availability and selectivity for the target organisms. The present study aimed to evaluate the fumigant activity of allyl isothiocyanate (AITC) on the development of $C$. maculatus and its effect on the physical properties of the cowpea. To evaluate the instantaneous population growth rate $\left(\mathrm{r}_{\mathrm{i}}\right)$, the insects were exposed to concentrations of 3.81, 5.71, 7.67, 9.41 and $17.85 \mathrm{~mL} \mathrm{AITC} \mathrm{m}^{-3}$ cowpea (corresponding to $\mathrm{LC}_{1}, \mathrm{LC}_{10}, \mathrm{LC}_{30}, \mathrm{LC}_{50}$ and $\mathrm{LC}_{95}$ ) for 40 days, after which the physical properties of the cowpea were analyzed. The degree of infestation increased considerably with the reduction in AITC concentration, as did the water content and electrical conductivity. The germination percentage and apparent density decreased with the reduction in AITC concentration. The $\mathrm{LC}_{10}$ sublethal concentration reduced reproduction in C. maculatus and the degree of infestation of the cowpea after 40 days of storage. AITC inhibits the development of C. maculatus and helps maintain the physical properties of the cowpea, thereby representing an alternative to the use of traditional insecticides and showing potential for the control of insect pests in stored grain.
\end{abstract}

Key words: Vigna unguiculata. AITC. Sinigrin. Callosobruchus maculatus. Bioinsecticide.

\begin{abstract}
RESUMO - O feijão-caupi está sujeito a perdas quantitativas e qualitativas durante o armazenamento devido ao ataque do inseto-praga Callosobruchus maculatus (Fabricius) (Coleoptera: Chrysomelidae). Para seu controle, é crescente o interesse por inseticidas proveniente das reações de metabólitos secundários produzidos por plantas, em decorrência de sua alta eficiência, ampla disponibilidade e seletividade para organismos alvos. Desta forma, o presente trabalho teve como objetivo avaliar a atividade fumigante do isotiocianato de alilo (AITC) no desenvolvimento de $C$. maculatus e seu efeito nas propriedades físicas do feijão-caupi. Para avaliação da taxa instantânea de crescimento populacional $\left(\mathrm{r}_{\mathrm{i}}\right)$ os insetos foram expostos às concentrações de AITC de 3,81, 5,71, 7,67, 9,41 e 17,85 mL m ${ }^{-3}$ de feijão-caupi, correspondentes às $\mathrm{CL}_{1}, \mathrm{CL}_{10}, \mathrm{CL}_{30}, \mathrm{CL}_{50}$ e $\mathrm{CL}_{95}$, durante 40 dias. Ao final deste período, as propriedades físicas do feijão-caupi foram analisadas. O grau de infestação aumentou consideravelmente com o decréscimo da concentração de AITC, assim como o teor de água e a condutividade elétrica. O percentual de germinação e a massa específica aparente diminuíram com a redução da concentração de AITC. A concentração subletal $\mathrm{CL}_{10}$ diminuiu a reprodução de C. maculatus e o grau de infestação dos grãos de feijão-caupi depois de 40 dias de armazenamento. O AITC inibe o desenvolvimento da espécie $C$. maculatus e contribui para a manutenção das propriedades físicas do feijão-caupi. Dessa forma, o AITC representa uma alternativa ao uso de inseticidas tradicionais além de apresentar potencial para o controle de insetos-praga de grãos armazenados.
\end{abstract}

Palavras-chave: Vigna unguiculata. AITC. Sinigrina. Callosobruchus maculatus. Bioinseticida.

DOI: $10.5935 / 1806-6690.20210019$

Editor-in-Article: Prof. Alek Sandro Dutra - alekdutra@ufc.br

*Author for correspondence

Received for publication on 06/04/2020; approved on 14/10/2020

'Part of the first author's master thesis through CNPq grant funding

²Departamento de Engenharia Agrícola, Universidade Federal de Viçosa, Viçosa-MG, Brasil; ailyn.ovilela@gmail.com (ORCID ID 0000-0003-3827-6451) lfaroni@gmail.com (ORCID ID 0000-0001-8648-5034), zjessicalino@ gmail.com (ORCID ID 0000-0002-1684-9944)

${ }^{3}$ Centro de Ciências Biológicas e da Natureza, Universidade Federal do Acre, Rio Branco-AC, Brasil, adalbertohipolito@ hotmail.com (ORCID ID 0000-0002-3089-2762)

${ }^{4}$ Departamento de Estatística, Universidade Federal de Viçosa, Viçosa-MG, Brasil, cecon@ufv.com (ORCID:ID 0000-0001-8213-0199) 


\section{INTRODUCTION}

The cowpea [Vignaunguiculata (L.) Walp.] has a positive impact on the diet of the population of tropical and subtropical regions of Africa, Asia, Europe and the Americas as it is rich in proteins, minerals, vitamins and fibers, and is quick to cook (DESHPANDE et al., 2011). During storage, the cowpea suffers both quantitative and qualitative loss due to attack by Callosobruchus maculatus (Fabricius) (Coleoptera: Chrysomelidae) (BECK; BLUMER, 2014). The damage caused by this insect pest is a result of the interior of the grain being colonized by the larvae, which feed on the grain and develop into adulthood, causing a reduction in weight, commercial value, nutritional value and product health due to the presence of feces, eggs and insects, in addition to a reduction in seed germination (AKAMI et al., 2017; OKE et al., 2015).

The management of insect pest infestations in stored products depends on synthetic substances of high toxicity (MANSOUR et al., 2012). Phosphine $\left(\mathrm{PH}_{3}\right)$ is the most used synthetic fumigant for controlling $\mathrm{C}$. maculatus in stored products (FREITAS et al., 2016; FREITAS; FARONI; SOUSA, 2016; SOUZA et al., 2018). However, the continuous and indiscriminate use of this insecticide can trigger the emergence of resistant populations in stored units and pose risks to man and the environment (TAY; BECKETT; BARRO, 2016). Among the alternatives used to control the pest, important is allyl isothiocyanate (AITC), a botanical insecticide of reported fumigant toxicity to $C$. maculatus (SOUSA et al., 2014; VILELA et al., 2020).

Plants are a rich source of secondary substances that may be bioactive against insect pests (BENELLI et al., 2019; MANSOUR et al., 2012). In family Brassicaceae, glucosinolates are secondary metabolites rich in nitrogen and sulfur (QUILES et al., 2019), whose formation is influenced by biotic and abiotic factors. Glucosinolates undergo hydrolysis due to tissue damage, resulting in biologically active compounds such as isothiocyanates (ITCs) and nitriles (YADAV; RANA, 2018). Sinigrin is a glucosinolate found in species of Brassicae; after hydrolyzation by the myrosinase enzyme, is converted into allyl isothiocyanate (AITC), which is found in higher concentrations in species of mustard, horseradish and wasabi, and shows considerable variation between cultivars of the same species (YU et al., 2003). AITC is a volatile compound, with a pungent aroma, showing the biological effects of an insecticide (FREITAS et al., 2016; MANSOUR et al., 2012; SANTOS et al., 2011; WU et al., 2014), and is possibly the compound with the greatest potential for biofumigation among the products of glucosinolate degradation (MAYTON et al., 1996). In addition to being obtained naturally through the hydrodistillation of plant tissue of genus Brassica, AITC can be synthesized by the reaction of allyl chloride and potassium thiocyanate (ROMANOWSKI; KLENK, 2005), avoiding the obstacles arising from cultivation, such as contamination and varying composition.

Recent studies have evaluated the toxicity of botanical compounds to different insect pests in stored grain, however, there are few that relate their lethal and sublethal effects to the quality of the treated grain after infestation. The aim of this study, therefore, was to evaluate the effect of AITC on instantaneous population growth rate in $C$. maculatus and its effect on the physical properties of infested cowpea grain.

\section{MATERIAL AND METHODS}

The BRS Guariba variety of cowpea was used, presenting a $3 \%$ degree of infestation by insects, a water content of $10 \%$ (wb), specific weight of $796 \mathrm{~kg} \mathrm{~m}^{-3}$, germination of $90 \%$ and electrical conductivity of $170 \mu \mathrm{S} \mathrm{cm}^{-1} \mathrm{~g}^{-1}$. The commercial formulation of AITC (94\% purity) was purchased from Sigma-Aldrich, in the United States.

The population of $C$. maculatus, obtained from the district of Crato in Ceará in 2014, was bred at the Laboratory for the Integrated Management of Grain Pests of the Federal University of Viçosa, Minas Gerais, in 1.5-L glass containers that were sealed with a perforated plastic cover, coated internally with organza to allow for gas exchange and maintained under a controlled temperature in a BOD climate chamber $\left(27 \pm 2{ }^{\circ} \mathrm{C}\right)$, constant relative humidity $(60 \pm 5 \%)$ and 24 -h scotophase. To form the insect colony, adults of $C$. maculatus were confined for 10 days to lay their eggs in cowpea grain that was free of pesticides, in the proportion of 20 insects to each $50 \mathrm{~g}$ of substrate, as recommended by Beck and Blumer (2014). The infested cowpea was stored until the emergence of the $F_{1}$ generation and was sieved every day to remove the emerged adults and maintain the age at 24 hours. This procedure was continued throughout the period of the bioassay.

\section{Sublethal effects on the instantaneous population growth rate $\left(\mathbf{r}_{\mathrm{i}}\right)$}

Fifty adults of $C$. maculatus up to $24 \mathrm{~h}$ of age were subjected to the fumigation procedure in glass containers with a capacity of $0.3 \mathrm{~L}$, filled with cowpea (240 g $\pm 1 \mathrm{~g})$ and sealed. In the upper part of the container, a PVC support covered with organza was fitted at a height of $1 \mathrm{~cm}$ to form a plenum and store filter paper moistened with AITC. The infested grain was exposed to concentrations of 3.81, 5.71, 7.67, 9.41 and $17.85 \mathrm{~mL} \mathrm{~m}^{-3}$ cowpea, corresponding to the previously determined sublethal concentrations of $\mathrm{LC}_{1}, \mathrm{LC}_{10}, \mathrm{LC}_{30}$ and $\mathrm{LC}_{50}$, and one concentration of 
$\mathrm{LC}_{95}$, respectively (VILELA et al., 2020); the control treatment was carried out under the same conditions, but with no AITC. Each treatment was replicated four times. After fumigating for $24 \mathrm{~h}$, the bottles were opened, covered with organza, and stored under ideal conditions for the insects to develop (temperature of $27 \pm 2{ }^{\circ} \mathrm{C}$ and relative humidity of $60 \pm 5 \%$ ) for 40 days, enough time for the completion of one life cycle. At the end of this period, the instantaneous growth rate was calculated using the equation proposed by Walthalle Stark (1997) (Equation 1), based on the total number of insects obtained at the end of the storage period and on the initial number of insects.

$r_{i}=\frac{\left[\ln \left(\frac{N_{f}}{N_{0}}\right)\right]}{\Delta T}$

where $\mathrm{N}_{\mathrm{f}}=$ Final number of insects; $\mathrm{N}_{0}=$ Initial number of insects; $\triangle \mathrm{T}=$ Time variation (number of days the test was run).

\section{Quality analysis of the cowpea}

The quality of the cowpea was evaluated after 40 days of storage, as a function of the AITC concentration applied to the grain. The parameters degree of infestation, water content, apparent density, germination and electrical conductivity were evaluated.

To assess the percentage of grain damaged by the insects, two samples of 100 grains, chosen at random, were immersed in water for $24 \mathrm{~h}$, enough time to soften the grains. The grains were then cut and examined individually. In addition to grains that contained larvae, pupae or adult insects, each grain that showed an exit hole for the insect were considered infested, as recommended by the Rules for Seed Analysis (BRASIL, 2009). The result was obtained using the mean number of infested grains and expressed as a percentage.

The moisture content of the grain was determined using the oven method, as per the Rules for Seed Analysis (BRASIL, 2009), which prescribe the use of a forced air circulation oven at $105 \pm 3{ }^{\circ} \mathrm{C}$ for $24 \mathrm{~h}$. Three replications of $25 \mathrm{~g}$ grain were used, and the results expressed as a percentage on a wet basis (wb).

The apparent density was determined in three replications with the aid of a hectoliter balance (model 40, Dallemolle, Brazil), with a capacity of a quarter of a liter $(250 \mathrm{~mL})$. As the hectoliter weight of a sample varies according to its water content, simultaneous determinations were made (BRASIL, 2009).

The germination potential was determined as per Brasil (2009), in four replications of 50 grains distributed in rolls of Germitest paper toweling, moistened with an amount of distilled water equal to 2.5 times the weight of the dry substrate, and kept in a BOD germination chamber at $25^{\circ} \mathrm{C}$. The count was taken after seven days, and the results expressed as a percentage.
The electrical conductivity of the solution containing the cowpea grain was measured using the Cup or Mass Conductivity System (VIEIRA; CARVALHO, 1994). Four replications were carried out using 50 randomly selected whole grains. The grains were weighed and placed in plastic cups with $75 \mathrm{~mL}$ of deionized water. After soaking, the beans were placed in a BOD climate chamber at $27{ }^{\circ} \mathrm{C}$ for $24 \mathrm{~h}$. The resulting solution was used to read the electrical conductivity with a model mCA-150 meter (Tecnopon). The value given by the conductivity meter $\left(\mu \mathrm{S} \mathrm{cm}^{-1}\right)$ was divided by the total weight of the 50 grains to give the value for electrical conductivity expressed in $\mu \mathrm{S} \mathrm{cm}^{-1} \mathrm{~g}^{-1}$.

\section{Statistical analysis}

The data for instantaneous growth rate and grain quality were submitted to regression analysis as a function of the AITC concentration. The data for grain quality were also analyzed using the canonical correlation (PROC CANCORR; SAS INSTITUTE, 2011) between the rate of infestation and the qualitative variables of the cowpea. The mean values were compared by Tukey's test using the Statistica v10 software (STATSOFT, INC., Tulsa, OK, USA); the graphs were plotted using the SigmaPlot 13.1 software (SYSTAT SOFTWARE, INC., San Jose, CA, USA).

\section{RESULTS AND DISCUSSION}

\section{Instant population growth rate $\left(\mathbf{r}_{\mathbf{i}}\right)$}

Exposure of the insects to sublethal concentrations of AITC in the cowpea significantly influenced the instantaneous population growth rate in species $C$. maculatus $\left(\mathrm{F}=286.55\right.$; g.1. error $\left._{\text {in }}=18 ; \mathrm{P}<0.0001\right)$. The value for $r_{i}$ decreased with increases in the AITC concentration over 40 days, which proves the inhibitory effect of AITC on the growth of $C$. maculatus. The three-parameter sigmoidal model $(y=a /(1+\exp (-(x-b) / c)))$ best fitted the reduction in $r_{i}$ for increases in the AITC concentration (Figure 1).

Figure 1 - Instantaneous population growth rate in C. maculatus as a function of the AITC concentration

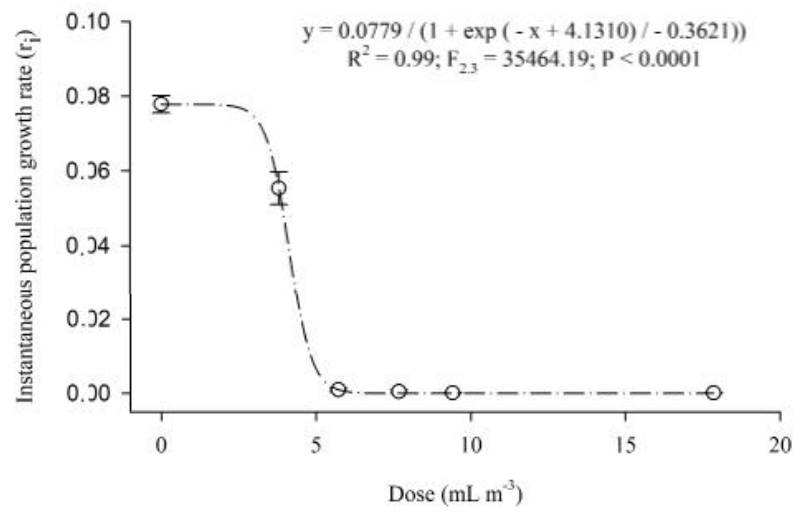


Starting with the AITC concentration of $5.7 \mathrm{~mL} \mathrm{~m}^{-3}$, corresponding to $\mathrm{LC}_{10}$, the instantaneous population growth rate was approximately zero, indicating that, although $\mathrm{LC}_{10}$ does not cause adult mortality, this concentration inhibits population development. Similar results were found by Moura et al. (2019) when studying the essential oil of Eremanthus arboreus in the control of C. maculatus. Souza et al. (2018) found that exposure to essential oils can reach the inner layers of the grain, which interferes directly with larval development and consequently leads to the interruption of adult emergence. The reduction in $r_{i}$ is associated with a shorter survival period for the adult insects in grain treated with high concentrations, preventing oviposition and progeny, and linked to the possible toxic effects of the oils on the insect eggs and larvae (JUMBO et al., 2014; MOURA et al., al., 2019).

\section{Physical properties of grain treated with allyl isothiocyanate}

The physical properties of the cowpea were influenced by the sublethal exposure to AITC. The higher the concentration applied to cowpea infested with 50 insects, the lower the instantaneous population growth rate in $C$. maculatus and, consequently, the lower the damage in the grain stored for 40 days. A significant canonical correlation (Wilks' Lambda = 0.0014; F = 2505.46; gl (num/den) $=5 / 18 ; \mathrm{P}<0.0001$ ) was found between the $\mathrm{r}_{\mathrm{i}}$ of the $C$. maculatus population and the group of characteristics used to express the quality of the cowpea grain subjected to different concentrations of AITC (degree of infestation, water content, germination, apparent density and electrical conductivity). The association between $r_{i}$ and this group of characteristics was high (0.99).

As the instantaneous population growth rate was low, the physical and physiological characteristics were maintained throughout the 40-day period. The correlation analysis indicates that the degree of infestation, water content and electrical conductivity of the cowpea increased with the increase in $r_{i}$, with a degree of correlation of $0.97,0.98$ and 0.93 , respectively, and that germination and specific weight decreased with the increase in $r_{i}$. That is, as the AITC concentration increased, the value of $r_{i}$ approached zero and all the physical characteristics of the grain remained close to their initial value when characterizing the grain (Table 1).

Treating cowpea with AITC made it possible to control the infestation of $C$. maculatus and preserve the quality of the grain during storage, except for the grain treated with the minimum concentration $\left(\mathrm{LC}_{1}\right)$. Grain infestation increased substantially, increasing the water content and, consequently, the loss of grain quality (Table 1). One of the principal causes associated with a loss of grain quality during storage is the increase in water content, especially when associated with a degree of infestation, mites and fungi, and the storage conditions (FREITAS; FARONI; SOUSA, 2016).

Increasing the AITC concentration resulted in a significant variation in the degree of infestation $(F=1217.66$; g.l error $\left._{1}=18 ; \mathrm{P}<0.0001\right)$. While the untreated cowpea grain was $100 \%$ infested by C. maculatus, $\mathrm{LC}_{10}$ afforded an $87.37 \%$ reduction in grain infestation. Furthermore, from $\mathrm{LC}_{30}$ onwards, the degree of infestation remained constant (Figure 2A) and close to the value found when characterizing the grain $(3 \%)$ (Table 1$)$.

The water content varied significantly in relation to the concentration used in the treatment of cowpea infested by C. maculatus $\left(\mathrm{F}=265.01 ;\right.$ g.1. $\left._{\text {error }}=18 ; \mathrm{P}<0.0001\right)$. From $\mathrm{LC}_{10}$ onward, the moisture content of the grain remained equal to the initial value (10\%) (Table 1, Figure $2 \mathrm{~B})$. In the untreated grain, the water content reached $21 \%$ due to the greater presence and biological activity of the insects. A high water content favors the development of fungi in the grain, impairing its storage quality (ALENCAR et al., 2009) and further increasing the water content, which is related to the biological activity of insects, fungi and mites, in addition to being influenced by incorrect storage (FREITAS; FARONI; SOUSA, 2016; MUTUNGI et al., 2015; SILVA et al., 2018).

Table 1 - Quality of cowpea infested by Callosobruchus maculatus as a function of allyl isothiocyanate concentration, and compared to the initial values when first characterizing the grain

\begin{tabular}{|c|c|c|c|c|c|}
\hline \multirow{2}{*}{ Concentration } & \multicolumn{5}{|c|}{ Quality Variables of the Cowpea } \\
\hline & Degree of Infestation $(\%)$ & Water Content (\%) & Germination (\%) & Specific Weight $\left(\mathrm{kg} \mathrm{m}^{-3}\right)$ & Electrical Conductivity $\left(\mu \mathrm{S} \mathrm{cm}^{-1} \mathrm{~g}^{-1}\right)$ \\
\hline Control & $100.0 \mathrm{a}$ & $21.0 \mathrm{a}$ & $27.5 \mathrm{a}$ & $651.3 \mathrm{a}$ & $328.1 \mathrm{a}$ \\
\hline $\mathrm{CL}_{1}$ & $100.0 \mathrm{a}$ & $15.9 \mathrm{~b}$ & $78.0 \mathrm{~b}$ & $728.0 \mathrm{~b}$ & $302.4 \mathrm{~b}$ \\
\hline $\mathrm{CL}_{10}$ & $12.6 \mathrm{~b}$ & $10.5 \mathrm{c}$ & $89.3 \mathrm{~b}$ & $784.8 \mathrm{c}$ & $251.2 \mathrm{c}$ \\
\hline $\mathrm{CL}_{30}$ & $6.6 \mathrm{bc}$ & $10.4 \mathrm{c}$ & $89.3 \mathrm{~b}$ & $784.8 \mathrm{c}$ & $234.8 \mathrm{~cd}$ \\
\hline $\mathrm{CL}_{50}$ & $4.0 \mathrm{c}$ & $10.2 \mathrm{c}$ & $89.8 \mathrm{~b}$ & $786.0 \mathrm{c}$ & $223.7 \mathrm{~d}$ \\
\hline $\mathrm{CL}_{95}$ & $3.5 \mathrm{c}$ & $10.2 \mathrm{c}$ & $89.8 \mathrm{~b}$ & $786.3 \mathrm{c}$ & $215.8 \mathrm{~d}$ \\
\hline Initial Characterization & $3.0 \mathrm{c}$ & $10.00 \mathrm{c}$ & $90.0 \mathrm{~b}$ & $796.0 \mathrm{c}$ & $170.0 \mathrm{e}$ \\
\hline
\end{tabular}

Mean values followed by the same letter in a column do not differ at a level of $5 \%$ by Tukey's test 
Figure 2 - Physical properties of cowpea infested by Callosobruchus maculatus as a function of allyl isothiocyanate concentration, and their respective nonlinear regression equations

A.

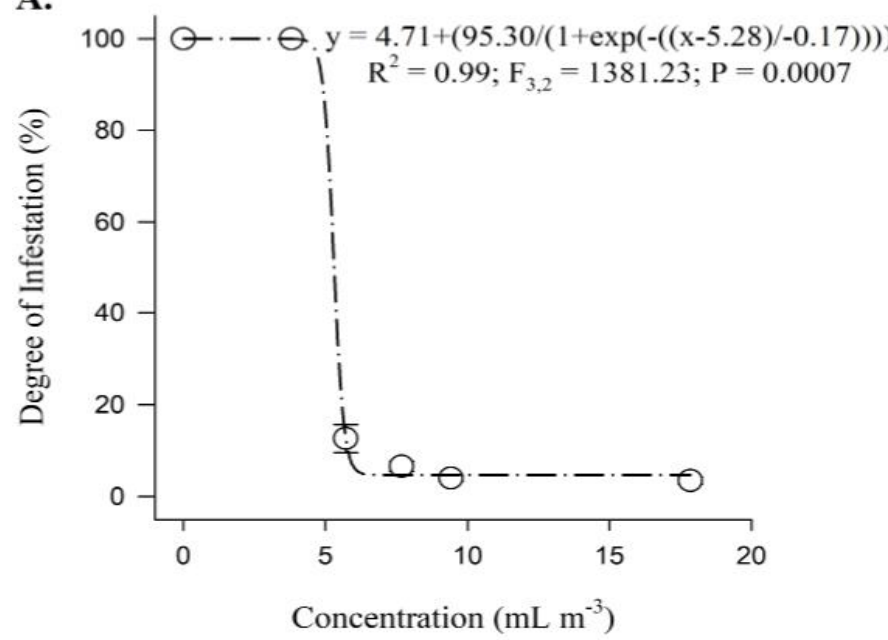

B.

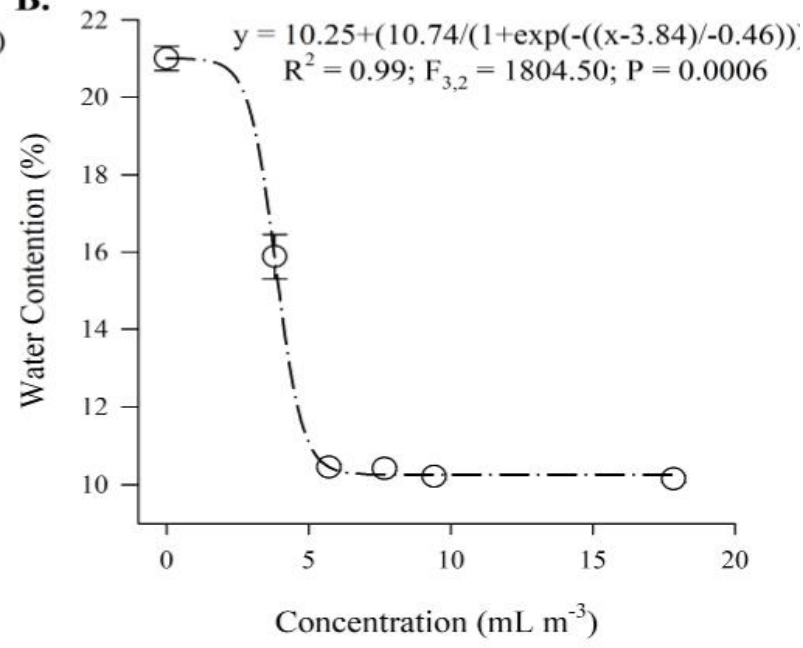

C.

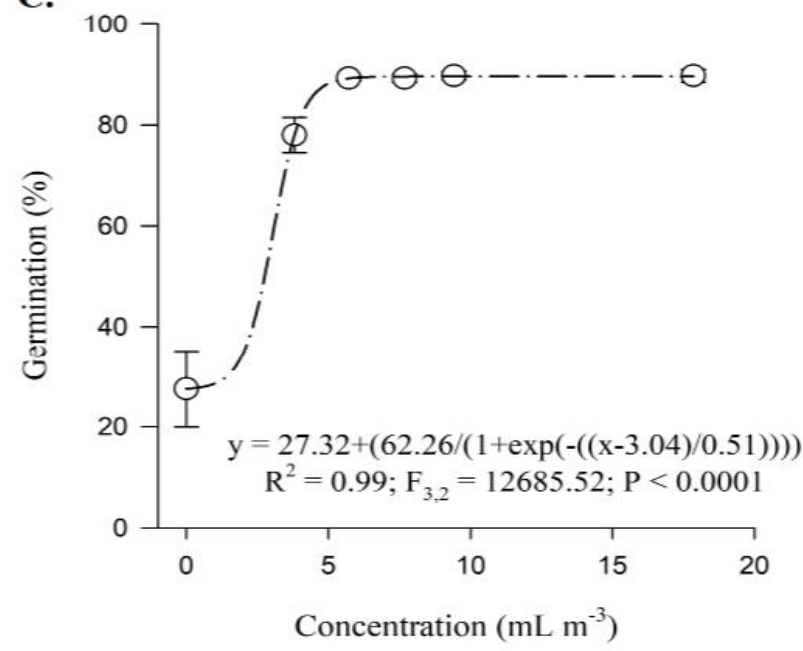

D.

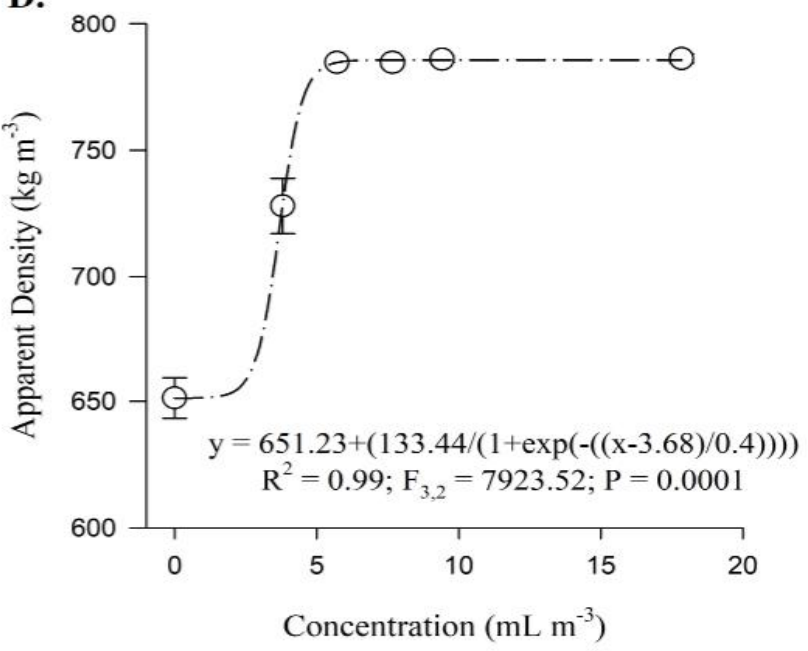

E.

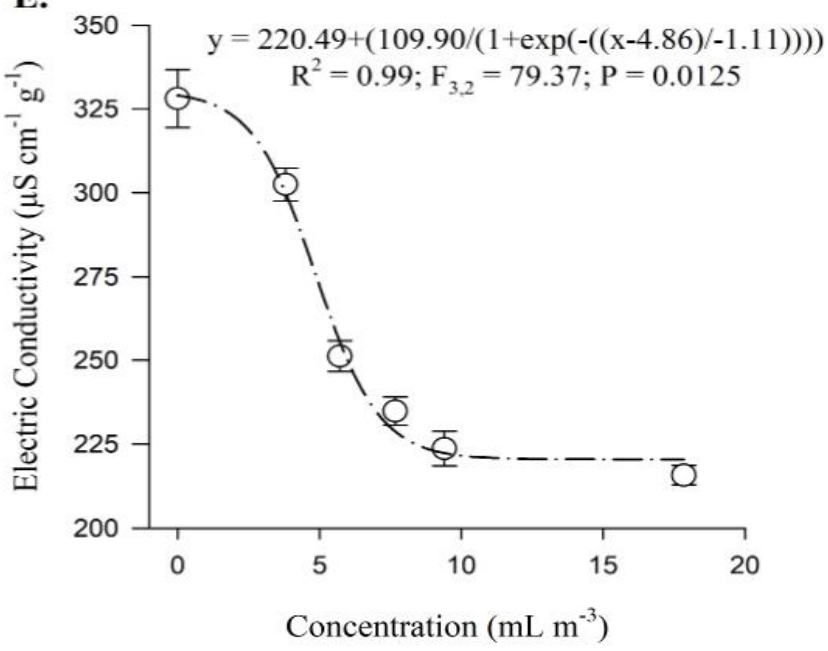


The germination percentage also varied significantly between treatments $\left(\mathrm{F}=50.68\right.$; g.1. error $\left._{\text {r }}=18 ; \mathrm{P}<0.0001\right)$. A marked reduction in germination was seen in the untreated cowpea compared to the initial value for germination (90\%), whereas the grain treated with at least $\mathrm{LC}_{10}$ maintained germination close to this value (Table 1, Figure 2C). During development of the insect population, the larvae of $C$. maculatus consume the interior of the grain and sometimes destroy the embryo during feeding, reducing the germination capacity of the product (VALES et al., 2014).

The apparent density of cowpea treated with AITC differed significantly between the control and the different concentrations $\left(\mathrm{F}=96.2 ; \mathrm{g} \mathrm{l}_{\text {error }}=18\right.$; $\mathrm{P}<0.0001)$. Since in the treated grain, C. maculatus infestation is inhibited and, consequently, less matter is consumed by the larvae, the application of $\mathrm{LC}_{10}$ to control the insects afforded a reduction of only $1 \%$, maintaining the initial value of the apparent density of the grain $\left(796 \mathrm{~kg} \mathrm{~m}^{-3}\right.$ ) (Table 1, Figure 2D). Insect pest infestation of stored grain leads to a reduction in apparent density, as the insects damage the integument and the larvae feed on the content, causing a reduction in dry matter (MUTUNGI et al., 2015). Seeds with low specific weight are more deteriorated, and quickly lose their viability during storage (ALENCAR et al., 2009).

The infestation by $C$. maculatus also led to an increase in the electrical conductivity of the grain, which varied significantly as a function of the AITC concentration $\left(\mathrm{F}=72.61 ;\right.$ g.l. $\left._{\text {error }}=18 ; \mathrm{P}<0.0001\right)$. Higher values for electrical conductivity represent greater amounts of leachate in the solution and are related to the integrity of the cell membranes (SMIDERLE et al., 1997). In the cowpea, the adult of $C$. maculatus breaks the outer wall of the grain when emerging, increasing the electrolytic leaching of solutes and, consequently, the electrical conductivity (FREITAS; FARONI; SOUSA, 2016). Although the treatment with AITC reduces the electrical conductivity, maintaining the initial value may be made difficult by the AITC itself, as which is a chemical compound subject to degradation.

Treating cowpea infested by $C$. maculatus with AITC vapor maintained the water content and inhibited the development of insects, preventing such damage as a loss of matter, deterioration of the cell membrane, increase in the water content and the proliferation of microorganisms in the grain.

\section{CONCLUSION}

The use of allyl isothiocyanate (AITC) did not affect the physical properties of the cowpea, playing a fundamental role in preserving these characteristics and in controlling infestation by Callosobruchus maculatus. From $\mathrm{LC}_{10}\left(5.7 \mathrm{~mL} \mathrm{~m}^{-3}\right.$ grain), development of $C$. maculatus in the cowpea grain was inhibited and, as a result, the quality of the grain was preserved. Allyl isothiocyanate (AITC) is a grain fumigant for the control of the bruchid C. maculatus in the cowpea.

\section{ACKNOWLEDGEMENTS}

The authors would like to thank the Conselho Nacional de Desenvolvimento Científico e Tecnológico - CNPq for the master's scholarship awarded the lead author. This study was carried out with the support of the Coordenação de Aperfeiçoamento de Pessoal de Nível Superior - Brasil (CAPES), under Finance Code 001.

\section{REFERENCES}

AKAMI, M. et al. Essential oil optimizes the susceptibility of Callosobruchus maculatus and enhances the nutritional qualities of stored cowpea Vignaun guiculata. Royal Society Open Science, v. 4, n. 8, p. 1-12, 2017.

ALENCAR, E. R. et al. Qualidade dos grãos de soja armazenados em diferentes condições. Revista Brasileira de Engenharia Agrícola e Ambiental, v. 13, n. 5, p. 606-613, 2009.

BECK, C. W.; BLUMER, L. S. A handbook on bean beetles, Callosobruchus maculatus. National Science Foundation. 2014. Disponível em: https://www.beanbeetles.org/handbook. pdf. Acesso em: 31 mar. 2020.

BENELLI, G. et al. Insecticidal efficacy of the essential oil of jambú (Acmella oleracea (L.) RK Jansen) cultivated in central Italy against filariasis mosquito vectors, houseflies and moth pests. Journal of Ethnopharmacology, v. 229, p. 272-279, 2019.

BRASIL. Ministério da Agricultura, Pecuária e Abastecimento. Regras para análise de sementes. Brasília: Mapa/ACS, 2009. 395 p.

DESHPANDE, V. K. et al. Quantitative and qualitative losses caused by Callosobruchus maculatus in cowpea during seed storage. Plant Archives, v. 11, n. 2, p. 723-731, 2011.

FREITAS, R. C. P. et al. Allyl isothiocyanate actions on populations of Sitophilus zeamais resistant to phosphine: Toxicity, emergence inhibition and repellency. Journal of Stored Products Research, v. 69, p. 257-264, 2016.

FREITAS, R. S.; FARONI, L. R. D.; SOUSA, A. H. Hermetic storage for control of common bean weevil, Acanthoscelides obtectus (Say). Journal of Stored Products Research, v. 66, p. 1-5, 2016.

JUMBO, L. O. V. et al. Potential use of clove and cinnamon essential oils to control the bean weevil, Acanthoscelides obtectus Say, in small storage units. Industrial Crops and Products, v. 56, p. 27-34, 2014. 
MANSOUR, E. E. et al. Effect of allyl isothiocyanate on Sitophilus oryzae, Tribolium confusum and Plodia interpunctella: toxicity and effect on insect mitochondria. Cropprotection, v. 33, p. 40-51, 2012.

MAYTON, H. S. et al. Correlation of fungicidal activity of Brassica species with allyl isothiocyanate production in macerated leaf tissue. Phytopathology, v. 86, n. 3, p. 267-271, 1996.

MOURA, E. S. et al. Insecticidal activity of Vanillosmopsis arborea essential oil and of its major constituent $\alpha$-bisabolol against Callosobruchus maculatus (Coleoptera: Chrysomelidae). Scientific Reports, v. 9, n. 1, p. 1-8, 2019.

MUTUNGI, C. M. et al. Triple-layer plastic bags protect dry common beans (Phaseolus vulgaris) against damage by Acanthoscelides obtectus (Coleoptera: Chrysomelidae) during storage. Journal of Economic Entomology, v. 108, n. 5, p. 2479-2488, 2015.

OKE, O. A. et al. Reduction of the nutritional values of cowpea infested with Callosobruchus maculatus (Coloeptera: Bruchidae). International Journal of Current Microbiology and Applied Sciences, v. 4, n. 8, p. 912-918, 2015.

QUILES, J. M. et al. Development of an antifungal and antimycotoxigenic device containing allyl isothiocyanate for silo fumigation. Toxins, v. 11, n. 3, p. 137, 2019.

ROMANOWSKI, F.; KLENK, H. Thiocyanates and isothiocyanates, organic. In: DEGUSSA, A. G. Ullmann's Encyclopedia of Industrial Chemistry. Wiley-VCH, 2005. p. 749-759.

SANTOS, J. C. et al. Fumigant toxicity of allyl isothiocyanate to populations of the red flour beetle Tribolium castaneum. Journal of Stored Products Research, v. 47, n. 3, p. 238-243, 2011.

SAS INSTITUTE. SAS/STAT user's guide. version 9.3. Cary, NC, USA: SAS Institute Inc., 2011.

SILVA, M. G. et al. Hermetic storage as an alternative for controlling Callosobruchus maculatus (Coleoptera: Chrysomelidae) and preserving the quality of cowpeas. Journal of Stored Products Research, v. 78, p. 27-31, 2018.

SMIDERLE, O. J. et al. Qualidade física e fisiológica de sementes de arroz irrigado (Oryza sativa L.) submetidos ao ataque de Rhizopertha dominica Fabricius e Sitophilus sp. durante o armazenamento. Revista Brasileira de Sementes, v. 19, n. 1, p. 1-8, 1997.

SOUSA, A. H.; FARONI, L. R. D.; FREITAS, R. S. Relative toxicity of mustard essential oil to insect-pests of stored products. Revista Caatinga, v. 27, p. 222-226, 2014.

SOUZA, L. P. et al. Toxicity and sublethal effects of allyl isothiocyanate to Sitophilus zeamais on population development and walking behavior. Journal of Pest Science, v. 91, n. 2, p. 761-770, 2018.

TAY, W. T.; BECKETT, S. J.; BARRO, P. J. Phosphine resistance in Australian Cryptolestes species (Coleoptera: Laemophloeidae): perspectives from mitochondrial DNA cytochrome oxidase I analysis. Pest Management Science, v. 72, p. 1250-1259, 2016.

VALES, M. I. et al. Effective and economic storage of pigeonpea seed in triple layer plastic bags. Journal of Stored Products Research, v. 58, p. 29-38, 2014.

VIEIRA, R. D.; CARVALHO, N. M. Testes de vigor em sementes. Jaboticabal: FUNEP, 1994. 164 p.

VILELA, A. O. et al. Toxicological and physiological effects of allyl isothiocyanate upon Callosobruchus maculatus. Journal of Stored Products Research, v. 87, p. 101625, 2020.

WALTHALL, W. K.; STARK, J. D. A comparison of acute mortality and population growth rate as endpoints of toxicological effect. Ecotoxicology and Environmental Safety, v. 37, n. 1, p. 45-52, 1997.

WU, H. et al. Effect of allyl isothiocyanate on ultra-structure and the activities of four enzymes in adult Sitophilus zeamais. Pesticide Biochemistry and Physiology, v. 109, p. 12-17, 2014.

YADAV, M.; RANA, J. S. Quantitative analysis of Sinigrin in Brassica juncea. Journal of Pharmacognosy and Phytochemistry, v. 7, n. 2, p. 948-954, 2018.

YU, J. C. et al. Chemical composition of the essential oils of Brassica juncea (L.) Coss. grown in different regions, Hebei, Shaanxi and Shandong, of China. Journal of Food Drug Analisys, v. 11, p. 22-26, 2003. 